\title{
Determinants of primary school dropout in Nawalparasi District
}

N. Manandhar ${ }^{1}$, A. B. Sthapit ${ }^{2}$

${ }^{1}$ Assistant Professor, Department of Community Medicine College of Medical Sciences, Bharatpur, ${ }^{2}$ Chairman and Professor, Central Department of Statistics, Kirtipur, Nepal

\begin{abstract}
Nepal's school education is structured as ECD / PPC, primary, lower secondary, secondary and higher secondary education. There are 29,220 primary schools. Any school children absent in the school for four consecutive weeks or more who failed to appear in final examination or next year in same school is considered as dropouts. To assess the causes of dropout in primary schools of Gaindakote Resource Centre of Nawalparasi district, a cross-sectional study was conducted in twelve schools of Gaindakote Resource Centre of Nawalparasi district during the period of Srawan / Bhadra, 2066 B.S. The highest dropout rate was found to be $8.43 \%$ in grade I and followed by $7.47 \%, 4.33 \%, 4.23 \%$ and $1.83 \%$ in grades II,III, IV andV respectively. The dropout rate for girls (5.87\%) was less than boys (6.14\%). Drop out is considered as huge waste of resources of the country as well as individual and it is a complex social problem. To reduce dropout rate in primary school, only free education will not solve the problem. So Government alone cannot solve it. Community must be made aware about the problems of drop out $\&$ parents are to be motivated for sending their children to school.
\end{abstract}

Key words: Education, dropout, causes, community.

\section{Introduction}

Nepal has 28.1 million populations and consists of 102 social groups and 92 languages. ${ }^{1}$ It is a landlocked heterogeneous country in terms of topography, climate and culture. Farming is the main occupation for nearly $80 \%$ of Nepal's population. Education is the principal instrument in awakening the child to cultural values and thus is the strongest force in the development and growth of a child in preparing him to be responsible, intelligent, strong and healthy citizen. Nepal still suffers with illiteracy. The literacy rate is only $64.4 \% .^{2}$ Nepal is one of the ten countries with least female literacy rate $(53.4 \%)$ in the world. Nepal's

Correspondence: N. Manandhar

Email: nareshsayami@yahoo.com school education is structured as early childhood development (ECD)/ pre-primary level (PPC), primary, lower secondary, secondary and higher secondary education. These schools include ECD/ PPC of one to three years duration. Primary schools provide five years of education to the 5-9 years of school-going age children and consists of five grades I-V. The lower secondary education consists of three years with the grade VI-VIII. Similarly, secondary and higher secondary education comprise two years each with grades IX-X and XIXII. There are 29,220 primary schools in Nepal. ${ }^{3}$ Vast majority of schools are government school. The numbers of private schools are also on the rise currently. Most of the private schools are concentrated in urban cities and district head 


\section{N. Manandhar et al, Determinants of primary school dropout in Nawalparasi District}

quarters. Over the last couple of decades Nepal has made remarkable progress in achieving the access to education.

Those children who enrolled in one school but failed to appear in final exam or next year at the same school or those students who are enrolled in the school but were absent in the school for four consecutive weeks or more are considered dropouts. Everyone has the right to education without distinction of any kind, such as race, colour, sex, language, religion, national or social origin, property, birth or other status. After the 20years of the UN Convention on the Rights of the child, large numbers of children in the South Asia are still denies to free $\&$ quality basic education. ${ }^{4}$ According to the Department of Education in 2008, each year there are $16.1 \%$ drop out in grade I. In grades II, III, IV, and V, dropout rates are $11.7 \%, 9.7 \%, 10.1 \%$, and $10.2 \%$ respectively. ${ }^{5}$ Grade repetition is also high in the Primary grades, which is about $29.5 \%$ in grade I, just over $10 \%$ in the grades II-IV and $7.8 \%$ in grade $\mathrm{V}$ in the year 2008. At present about $80 \%$ of primary school age children are enrolled in school and $45.4 \%$ of the children enrolled in primary levels leave schools without completing grade five.

School drop out is a complex social problem for which there is no simple solution. It needs attention on every problem. ${ }^{6}$ Many educators and others who are concerned with the dropout problem are advocating policies, which involve a broad range of institutions and agencies. Increasingly, it is being recognized that the issues of drop out and its prevention cannot be separated from issues affecting our total economic and social structure. These issues include poverty, unemployment, gender \& caste discrimination, child abuse, drug abuse in the family, and many other factors, which are associated with it. A substantial portion of Nepali children between the ages of 5 and 14 are involved in various forms of child labor, such as bonded labor, carpet industries and child prostitution. $^{7}$

\section{Materials and methods}

A cross sectional study was conducted in twelve schools of Gaindakote Resource Centre of Nawalparasi district during the period of Srawan / Bhadra, 2066 B.S. to assess the causes of dropout in primary schools. Eight Government and four private schools are randomly selected from 30 government and 10 private primary schools of Gaindakote Resource Centre with three village development committees (VDCs). School dropout children are identified from school register, consultation with class teachers and finally with the families. The pre-designed questionnaire was used for interview method to collect information about dropout children. The collected data were entered in SPSS software program and analysis was done.

\section{Results}

Table1: Dropout rates in percentage by grade and sex

\begin{tabular}{lcccccc}
\hline Student & \multicolumn{7}{c}{ Grade } & & & \\
& I & II & III & IV & V & I-V \\
\hline Girls & 7.98 & 7.83 & 4.28 & 4.52 & 0.70 & 5.87 \\
Boys & 8.87 & 7.01 & 4.39 & 3.87 & 3.03 & 6.14 \\
\hline Total & 8.43 & 7.47 & 4.33 & 4.23 & 1.83 & 6.00 \\
\hline
\end{tabular}

$\dot{\div}^{2}=0.8876$, at 4 Degree of freedom, $p$-value $=0.820$ 
The total dropout rate is not consistent with grade and sex. The highest dropout rate $(8.43 \%)$ was found in the grade I. The drop out rate was observed decreases with increase of grades. For the boys, the highest dropout rate $(8.87 \%)$ was observed in grade I and least dropout rate $(3.03 \%)$ observed in grade V. For the girls, the highest dropout rate (7.98\%) was observed in grade I in and least dropout rate $(0.70 \%)$ observed in grade V. Girl's drop out rate was found less than boy's in all primary grades except grade II where girl's dropout rate $(7.83 \%)$ was higher than boy's $(7.01 \%)$. There is not significant different in boys and girls dropout of primary school children as $\mathrm{p}$ value is more than 0.05 .

Table 2: The distribution according to grade and sex of total dropout children

\begin{tabular}{lcccccc}
\hline \multicolumn{2}{c}{ Grade } & \multicolumn{2}{c}{ Girl } & \multicolumn{2}{c}{ Boy } & \multicolumn{2}{c}{ Total } \\
& Number & $\%$ & Number & $\%$ & Number & $\%$ \\
\hline I & 14 & $(16.9 \%)$ & 15 & $(18.1 \%)$ & 29 & $(34.9 \%)$ \\
II & 8 & $(9.6 \%)$ & 10 & $(12.0 \%)$ & 18 & $(21.7 \%)$ \\
III & 4 & $(4.8 \%)$ & 9 & $(10.8 \%)$ & 13 & $(15.7 \%)$ \\
IV & 9 & $(10.8 \%)$ & 8 & $(9.6 \%)$ & 17 & $(20.5 \%)$ \\
V & 3 & $(3.6 \%)$ & 3 & $(3.6 \%)$ & 6 & $(7.2 \%)$ \\
\hline Total & 38 & $(45.8 \%)$ & 45 & $(54.2 \%)$ & 83 & $(100 \%)$ \\
\hline
\end{tabular}

$\div^{2}=1.66$ at 4 Degree of freedom, p-value $=0.798$

The number of dropout girl (38) was less than boys (45) in total dropout children. Among total dropout children, maximum volume of dropout observed in grade I (34.9\%) followed by $21.7 \%, 20.5 \%$, $15.7 \%$ and $7.2 \%$ in grades II, IV,III and V respectively.
Table 3: Age and sex wise distribution of dropout children

\begin{tabular}{cccc}
\hline Age in year & \multicolumn{1}{c}{ Sex } & \multicolumn{2}{c}{ Total } \\
& Boy & Girl & \\
\hline 5 & 2 & 0 & 2 \\
6 & 11 & 8 & 19 \\
7 & 9 & 12 & 21 \\
8 & 8 & 4 & 12 \\
9 & 8 & 4 & 12 \\
10 & 3 & 4 & 7 \\
11 & 2 & 3 & 5 \\
12 & 1 & 0 & 1 \\
13 & 0 & 1 & 1 \\
14 & 1 & 0 & 1 \\
15 & 0 & 2 & 2 \\
\hline Total & 44 & 38 & 83 \\
\hline$\div^{2}=10.3$ at 10 Degree of freedom, p-value $=0.437$
\end{tabular}

The majority (77.1\%) of drop out was found in ages 6 to 9 years of children then decreases as age increases. The highest $(25.3 \%)$ drop out was observed in age 7 years followed by 6 years with $22.89 \%$.

Table 4: Drop out according to different causes

\begin{tabular}{llcc}
\hline S.N. Causes & Number & $\%$ \\
\hline $1 \quad$ Work at home & 41 & 49.4
\end{tabular}

2 Could not purchase education material 29 34.9

3 Parents apathy toward education $24 \quad 28.9$

$\begin{array}{llll}4 & \text { Migration } & 15 & 18.1\end{array}$

$\begin{array}{llll}5 & \text { Not interest in study } & 6 & 7.2\end{array}$

6 Distance $\quad 3 \quad 3.6$

$\begin{array}{llll}7 & \text { Illness } & 2 & 2.4\end{array}$

8 Death of parents $\quad 3 \quad 3.6$

$\begin{array}{llll}9 & \text { Other marriage of parents } & 2 & 2.4\end{array}$

$\begin{array}{llll}10 & \text { Overage } & 2 & 2.4\end{array}$

\begin{tabular}{llll}
\hline 11 & Others & 8 & 9.8 \\
\hline
\end{tabular}


N. Manandhar et al, Determinants of primary school dropout in Nawalparasi District

Total of 2617 children were enrolled in these twelve-selected schools from grade 1-5. The number of girls and boys were almost same but more number of boys (58\%) was enrolled in private schools. Out of total children, 103 were dropout only from government schools. Among them 83 drop out children were traced and interviewed regarding the causes of drop out. The present study observed that the majority of dropout was due to house hold chore (49.4\%) and poor economic status of parents $(34.9 \%)$. The parent $(28.9 \%)$ had apathy towards their children's education and $18.1 \%$ of drop outs were due to migration of family.

\section{Discussion}

The dropout phenomenon not only wastes educational resources but also leads to a host of social and economic consequences. In developing countries from the findings of research it is observed that once the children are drop out in basic education, they rarely return for formal education. They also rarely become the skilled laborer, which in turn limits their earnings to subsistence-level income. Thus, a vicious cycle of economic and social poverty is perpetuated from one generation to the next. The National Plan of Action has outlined as per recommendation of the Dakar Forum for the year 2015 for complete, free and compulsory primary education of good quality expanding for the most vulnerable and disadvantaged children and ensuring that all children, particularly girls, children in difficult circumstances \& children belonging to ethnic minorities. ${ }^{8}$

In this study, more boys (58\%) were enrolled in private school than Government school $(47.4 \%)$ where parents have to pay for admission, monthly and exam fees where as these are free in the government school. It showed the gender bias. The sons were more preferred to enroll in private school where children get individual care. The present study revealed highest dropout rate $(8.43 \%)$ in grade I and least (1.83\%) in grade V. The dropout rates for grade II, III and IV were $7.47 \%, 4.33 \%$ and $4.23 \%$ respectively. These dropout rates were quite low when compared with national dropout rates, which were $16.15 \%, 11.7 \%, 9.7 \%, 10.15 \%$ and $10.2 \%$ respectively for grades $\mathrm{I}$ to $\mathrm{V}^{5}$. This difference may be due to change in time period and different study area.

All drop-outs (100\%) were observed in government schools only. This may be due to some fraudulent inflating of initial enrollment because Department of Education assigns teacher according to number of student enrolled. The main causes of primary school drop-out were house hold chores, economic strains and unawareness regarding the importance of education in the parents. In one of the study, it was observed that the main causes of dropout were found to be family poverty, household chores, and irregularity in attendance. While, over $45 \%$ of the dropouts were found engaged in household chores, another $41 \%$ of the drop outs were found doing nothing, and only $14 \%$ of the dropouts between the age group 6-15 were found to be engaged in wage labor. ${ }^{9}$ The present study revealed that $49.4 \% \%$ of dropout school children were due to household chore. Most of these children will look after their young siblings when their parents go for work. This result is almost similar to the result of studies in Kapilvastu district of $\mathrm{Nepal}^{9}$ and an inquiry into the causes of primary school drop-out 
Journal of College of Medical Sciences-Nepal,2010, Vol-6,No-4

in rural Nepal where these were $45 \%$ and $62.8 \%$ respectively. The drop out due to unawareness regarding the importance of education of their parent was $28.9 \%$. This figure was less than the study conducted by CERID where it was $48.9 \%{ }^{8}$ This difference may be due to change of time period and different study area. This study revealed that $34.9 \%$ of drop-out was due to inability to purchase the stationary material, dresses, and to pay exam fees because of the poor economic status of parents. This finding was consistent with the result of the study done by CERID where it was $38.4 \% .{ }^{10}$

\section{Conclusion}

The government of Nepal has made free primary education and free books distribution for all students. There is also some scholarship program for Dalit and girl students. In spite of that a high dropout rate in grade 1 was observed in the current study. It shows that the making free education is not sufficient to catch up all the school age children to continue in primary school. Drop out is considered as huge wastes of resources of the country as well as individual and it is a complex social problem. To reduce dropout rate of primary school children, only free admission \& monthly fees and book distribution will not solve the problem. No one should be failed in primary level. Government alone cannot solve it. So Community must be made aware \& motivated regarding the importance of education specially the parents.

\section{References}

1. National School Health and Nutritional Strategy, Govt. of Nepal, Ministry of Education and Sport, Ministry of Health and Population, Kathmandu, Nepal:2006;1-7.

2. Statistical Pocket Book, Govt. of Nepal. National Planning Commission Secretariat, Central Bureau of Statistics, Ramshahpath, Kathmandu, Nepal: 2002;3$4 \& 152-6$.

3. School Level Education Statistics of Nepal, Government of Nepal, Ministry of Education and Sports, Department of Education, Kathmandu: 2004; 3-4.

4. Developing rights-based education SWAps in South Asia from evidence to action,UNICEF regional office of South Asia,Kathmandu, Nepal 2008; 15-21.

5. Flash I Report 2064 (2007-08), Department of Education, Sanothimi, Bhaktapur, December, 2007;48-52.

6. The world development indicators, World Bank, 2000.

7. Child Workers in Nepal Concerned Center (CWIN), 2007;http//www.cwin/nepal.org.retrieved March 12, 2010.

8. Education for All, National Plan Of Action, HMG, Ministry of Education and Sports, Nepal National Commission for UNESCO, Kathmandu, Nepal, 2003;3-6.

9. V.B. Karki, Perceived Antecedents and Subsequent Activities of Primary School Children in Nepal,1997;3-6.

10. B.Thapa, Determinants of Educational Participation in Rural Nepal, CERID, 1984; 53-8. 